\title{
IMPLEMENTASI MODEL THINK TALK WRITE (TTW) TERHADAPKEMAMPUAN KOMUNIKASI MATEMATIS TULIS PESERTA DIDIK
}

\author{
Isti Muhlisotin $^{1^{*}}$, M. Ivan Ariful Fathoni' ${ }^{2}$, Anisa Fitri ${ }^{3}$ \\ 1,2, ${ }^{3}$ Prodi Pendidikan Matematika, Universitas Nahdlatul Ulama Sunan Giri \\ istimuhlisotin@gmail.com*1, fathoni@unugiri.ac.id ${ }^{2}$, anisafitri@unugiri.ac.id ${ }^{3}$ \\ *Corresponding Author
}

Received 25 October 2021; revised 09 December 2021; accepted 20 December 2021.

\begin{abstract}
ABSTRAK
Kemampuan komunikasi matematis ialah kemampuan peserta didik dalam menguasai pendapat matematika berupa diagram, tabel, simbol atau media yang lainnya. Paradigma pembelajaran Think Talk Write (TTW) ialah satu metode diantara yang lain dipakai untuk mengajarkan peserta didik bagaimana berkomunikasi secara lisan dan tulisan. Tujuan penelitian ini yaitu melihat kemampuan komunikasi matematis tulis peserta didik menggunakan model TTW di SMA N 3 Bojonegoro. Penelitian ini memakai metode deskripsi kuantitatif. Populasi penelitian ialah semua peserta didik kelas X-IPS dan sampelnya X-IPS 3 yang di pilih dengan teknik random sampling. Sumber data berasal dari hasil tes peserta didik. Akumulasi data pada penelitian ini menggunkan tes tertulis dan teknik wawancara. Berdasarkan pembahasan dan hasil perhitungan setiap uji bahwa kemampuan komunikasi matematis tulis peserta didik lebih baik dengan model Think Talk Write (TTW). Oleh sebab itu model TTW dapat dijadikan alternative dalam proses belajar.
\end{abstract}

Kata kunci: eksperimen, kemampuan komunikasi, Think Talk Write (TTW).

\begin{abstract}
Mathematical communication ability is the ability of students to master mathematical opinions in the form of diagrams, tables, symbols, or other media. The Think Talk Write (TTW) learning paradigm is one method used to teach students how to communicate orally and in writing. This study aims to see the ability of students' written mathematical communication skills using the TTW model at SMA N 3 Bojonegoro. This research uses the quantitative description method. The research population is all students of class X-IPS, and the sample is X-IPS 3. The data source comes from the results of student tests. Collecting data in this study using a written test and interview techniques. Based on the discussion and calculation results of each test that students' written
\end{abstract}


mathematical communication skills are better with the Think Talk Write (TTW) model. Therefore, the TTW model can be used as an alternative in the learning process.

Keywords: experiment, communication skills, Think Talk Write (TTW).

\section{PENDAHULUAN}

Matematika ialah ilmu terpenting dalam dunia pendidikan. Matematika merupakan sumber dari ilmu pengetahuan lainnya, menurut Hamzah (2014) akibat rumus, teorema, dan kontradiksi dalam matematika bisa membantu dalam mempelajari ilmu-ilmu yang lain, matematika disebut sebagai ratu atau pelayan ilmu pengetahuan. Matematika merupakan bidang wajib pada seluruh strata pendidikan, mulai dari Sekolah Dasar sampai Universitas. Selain diperlukan dalam pendidikan formal, di kehidupan sehari-hari pun matematika juga bisa digunakan. Saat ini Kurikulum di Indonesia menggunakan Kurikulum 2013. Tujuan dari kurikulum 2013 yaitu supaya peserta didik mempunyai kemampuan keterampilan keterampilan personal dan sosial tidak hanya mempunyai kemampuan kognitif saja, yang sering disebut dengan kemampuan 4C yaitu Comunication, Collaboration, Critical Thinking, dan Creativity. Dalam penelitian ini lebih berfokus pada Comunication (Komunikasi).

Komunikasi ialah suatu penyaluran informasi (pesan, ide, dan gagasan) dari individu ke orang lain. Komunikasi penting dalam pendidikan. Komunikasi penting dalam pendidikan matematika bukan hanya alat bantu berpikir, mengenali pola, mengatasi masalah dan menarik konklusi, itu juga merupakan instrument yang sangat berharga untuk menyajikan ide-ide dengan jelas, akurat, dan sederhana. Oleh karena itu komunikasi sangat penting dalam matematika, sebagai cara menghubungkan peserta didik dan sebagai sarana belajar (Umar, 2012). Menurut Wardhana (2018) komunikasi suatu kontribusi penting dalam pembelajaran sebab memungkinkan peserta didik untuk bertukar ide diantara mereka sendiri, temanteman mereka, guru, dan lingkungan mereka.

Komunikasi juga penting di dalam pendidikan terutama di sekolah, komunikasi memungkinkan peserta didik dapat menyampaikan pokok pikiran, gagasan, ide, pendapat serta tanggapan pada guru dan teman yang lain dalam proses pembelajaran. Masalah yang dihadapi peserta didik yaitu pada segi komunikasi, 
baik komunikasi lisan maupun komunikasi tulis. Komunikasi lisan ialah suatu percakapan yang cara menyampaikan sesuatu secara langsung pada lawan bicaranya tanpa ada perantara. Komunikasi lisan dapat dilihat dalam proses belajar peserta didik tidak bisa mengucapkan kembali apa yang sudah diucapkan oleh guru. Sedangkan komunikasi tulis adalah komunikasi yang dilakukan yang melalui sebuah tulisan. Komunikasi tulis dapat dilihat peserta didik tidak bisa menuliskan hasil jawaban soal yang diberikan guru dengan benar atau bahkan tidak mau menulis jawabannya sama sekali. Artinya peserta didik masih kesulitan dalam mengkomunikasikan gagasan dalam bentuk matematika.

Rahmawati dan Zhanty (2019) mengatakan kemampuan komunikasi sangat perlu karena matematika itu tidak sekedar simbol tanpa arti tetapi matematika yaitu bahasa yang mempunyai fungsi untuk membantu dalam kegiatan setiap hari dalam penyelesaian masalah. Tidak adanya komunikasi, semua orang akan sukar berkorelasi dengan lainnya. Setiyawan dkk (2019) mengungkapkan kemampuan peserta didik untuk menguasai ide-ide matematika berwujud diagram, symbol, tabel, atau media lainnya disebut dengan komunikasi matematis. berikut ini adalah indikator keterampilan komunikasi yang diusulkan dalam penelitian ini: (1) Writen text, yaitu menyusun respons dengan majas kebahasaannya sendiri; (2) Drawing, yaitu mengubah objek konkret, ilustrasi, atau grafik menjadi ekspresi matematis; (3) Mathematical expressions, ialah pengungkapan konsep matematis ke dalam kegiatan sehari-hari atau dalam simbol matematika.

Kemampuan komunikasi matematis peserta didik sebagian besar belum optimal. Hal ini terjadi di SMAN 3 Bojonegoro dimana peneliti pernah melaksanakan kegiatan Praktik Pengalaman Lapangan (PPL). Buktinya nilai ulangan harian peserta didik rata-rata mendapat 60. Selama satu bulan peneliti melaksanakan PPL saya melihat ada beberapa problematika yang dialami peserta didik, terutama problematika dibagian kemampuan komunikasi matematis peserta didik dan peneliti melangsungkan kegiatan wawancara secara tidak terstruktur kepada guru bidang matematika SMAN 3 Bojonegoro pada hari kamis tanggal 20 agustus 2020 lalu, ditemukan masalah yang memuat tentang kemampuan komunikasi matematis peserta didik. Para peserta didik masih rendah ketika 
penyampaian gagasan matematis mereka secara lisan ataupun tulisan, menjelaskan kembali materi yang dipelajari, dan menjawab pertanyaan.

Hal ini terlihat ketika pada materi Sistem Persamaan Linear Tiga Variabel (SPLTV) para peserta didik rata-rata masih kesukaran saat merancang model matematis untuk merespons soal cerita yang dibagikan guru, apalagi jika pertanyaan yang diajukan guru dengan yang dicontohkan itu tidak sama. Selain itu ketika diminta untuk menjelaskan cara menyelesaikan soal dipapan tulis, menyelesaikan pertanyaan dari guru, atau bertanya perihal pelajaran yang sudah dilampaui. Memilih model pembelajaran yang memotivasi peserta didik supaya ikut terjun langsung dalam pembelajaran aktif merupakan salah satu langkah yang bisa dilakukan. Belajar aktif dapat memaksimalkan kemampuan komunikasi matematis peserta didik, contohnya pembelajaran kooperatif.

Pembelajaran kooperatif ialah metode pengajaran dimana peserta didik dipecah menjadi beberapa grup dengan berbagai kategori kemampuan supaya dapat menaikkan pemahaman mata pelajaran, dan setiap anggota kelompok berkewajiban untuk mempelajari yang diajarkan beserta berkolaborasi dengan teman-temannya dalam belajar guna menumbuhkan sikap positif dalam lingkungan belajar. (Muhlisrarini, 2014). Pembelajaran kooperatif terdapat banyak tipe model pembelajaran, salah satunya ialah model pembelajaran tipe Think Talk Write. Model pembelajaran Think Talk Write ialah strategi pengajaran yang melatih peserta didik untuk menyampaikan sesuatu atau ide dengan maksimal baik lisan ataupun tulisan. Menurut Hamdayama (2014) menyatakan bahwa peserta didik dapat memakai model pembelajaran Think Talk Write (TTW) untuk mengkontruksi pengetahuannya sendiri, dan mereka dapat berkomunikasi atau memusyawarahkan idenya sesama teman sebayanya untuk saling berkolaborasi dan berbagi ide sehingga mereka dapat paham akan materi yang diajarkan. TTW juga dapat melatih peserta didik dalam menulis hasil diskusi secara tertulis. Berdasarkan uraian diatas, penulis mengambil tindakan pada skripsi yang berjudul Pengaruh Model Think Talk Write (TTW) Terhadap Kemampuan Komunikasi Matematis Tulis Peserta Didik Di SMAN 3 Bojonegoro. 


\section{METODE PENELITIAN}

Jenis penelitian ini ialah penelitian deskriptif kuantitatif. Menurut Sugiyono (2015) Penelitian kuantitatif ialah teknik penelitian yang berasaskan pada filosofi positivis yang mengkaji populasi ataupun sampel tertentu dengan mengambil teknik random sampling, instrument penelitian digunakan dalam pengumpulan data, dan untuk menguji hipotesis yang telah ditetapkan peneliti memakai data kuantitatif.

Penelitian ini dilaksanakan pada waktu tahun 2021/2022 di SMAN 3 Bojonegoro. Sekolah ini dipilih karena Sekolah ini dipilih karena tempat tersebut ada beberapa problematika yang dialami peserta didik terkhusus problematika dibagian kemampuan komunikasi matematis peserta didik. Permulaan penelitian dari persiapan (membuat proposal, seminar proposal, revisi proposal, lanjut penelitian ditempat yang sudah dipilih, ujian skripsi, revisi skripsi dan sampai penyerahan skripsi.

Subjek dalam penelitian populasinya ialah semua kelas X-IPS SMAN 3 Bojonegoro tahun ajaran 2021/2022. Terdiri dari 5 kelas yang masing-masing satu kelas terdapat 32 peserta didik. Sedangkan Sampel dalam penelitian ialah kelas XIPS 3 SMAN 3 Bojonegoro yang jumlahnya 32 peserta didik. Dalam pengambilan sampel yaitu dengan pengambilan sampel acak kelompok atau cluster random sampling.

Data penelitian bersumber dari hasil jawaban tes tulis peserta didik kelas XIPS 3 SMAN 3 Bojonegoro, hasil wawancara terhadap peserta didik berdasarkan kriteria masing-masing, dan hasil perhitungan uji analisis data. Instrument penelitian yang digunakan ada 2 yaitu tes tertulis dengan maksud untuk menaksir taraf kemampuan komunikasi matematis tulis peserta didik dan mengetahui sejauh mana pengetahuan peserta didik dalam mengungkapkan idenya kedalam bahasa tulisan berupa uraian atau essay dan wawancara yang tujuannya sebagai alat bantu pengambilan dan mengumpulan data. Prosedur yang digunakan ialah fase persiapan, fase pelaksanaan, fase analisis data, fase menyusun laporan akhir. Pengumpulan data penelitian diperoleh melalui tes tertulis bentuk essay, wawancara, dan dokumentasi langkah-langkah uji normalitas, uji homogenitas, uji hipotesis ialah cara peneliti dalam menganalisa data. 


\section{HASIL PENELITIAN DAN PEMBAHASAN}

Hasil dan pembahasan penelitian mencangkup uji normalitas, uji homogenitas, uji hipotesis, dan deskripsi hasil jawaban peserta didik sesuai kriteria masing-masing. Uji normalitas diperlukan untuk menganalisa data dari penelitian ini normal atau abnormal. Kemudian uji homogenitas digunakan untuk menganalisa populasi dalam penelitian ini homogen atau tidak dan uji hipotesis digunakan untuk menganalisa pengajuan hipotesis dari penelitian diterima atau ditolak. Yang terakkhir deskripsi hasil jawaban peserta didik digunakan untuk membedakan kepemahaman peserta didik dengan kriterianya yaitu tinggi, sedang, dan rendah. Perhitungan uji-uji tersebut berasal dari aplikasi excel. Berikut penjelasan lebih lengkapnya :

\section{Uji normalitas}

Tabel 1. Hasil Rekapitulasi Uji Normalitas Pre Test dan Post Test

\begin{tabular}{ccccccc}
\hline & $\overline{\boldsymbol{x}}$ & $\boldsymbol{S}$ & MAX & MIN & $\boldsymbol{l}_{\text {hitung }}$ & $\boldsymbol{l}_{\text {tabel }}$ \\
\hline Pre test & 36,78125 & 9,53342 & 50 & 0 & 0,0847 & 2,039513 \\
\hline Post test & 79,90625 & 7,87548 & 90 & 60 & 0,104652 & 2,039513 \\
\hline
\end{tabular}

Berdasarkan Tabel 1 terlihat rerata pre test sebesar 36,78125 sedangkan rerata post test sebesar 79,90625. Simpangan baku pre test sebesar 9,53342 dan post test sebesar 7,87548 dan $L_{\text {hitung }}$ sebesar 2,039513 sedangkan $L_{\text {tabel }}$ sebesar 2,039513. Jadi bisa diartikan karena $L_{\text {hitung }}<L_{\text {tabel }}$, berarti $H_{0}$ diterima. Maka data pada pre test dan post test berasal dari data yang berdistribusi normal.

\section{Uji homogenitas}

Tabel 2. Hasil Rekapitulasi Uji Homogenitas Pre Test dan Post Test

\begin{tabular}{ccccc}
\hline & $\overline{\boldsymbol{x}}$ & $\boldsymbol{S}^{\mathbf{2}}$ & $\boldsymbol{f}_{\text {hitung }}$ & $\boldsymbol{f}_{\text {tabel }}$ \\
\hline Pre test & 36,78125 & 90,88609 & \multirow{2}{*}{1,465357} & 1,822132 \\
\cline { 1 - 3 } Post test & 79,90625 & 62,02319 & & \\
\hline
\end{tabular}

Berdasarkan Tabel 2 terlihat rerata pre test sebesar 36,78125 sedangkan rerata post test sebesar 79,90625. Varians pre test sebesar 90,88609 dan post test sebesar 62,02319 dan $F_{\text {hitung }}$ pre test dan post test sebesar 1,465357 sedangkan $F_{\text {tabel }}$ pre test dan post test sebesar 1,822132. Jadi bisa diartikan karena bahwa 
$F_{\text {hitung }}<F_{\text {tabel }}$ yaitu $1,465357<1,822132$, berarti $H_{0}$ diterima. Maka sampel dari kedua populasi homogen.

\section{Uji hipotesis}

Tabel 3. Hasil Rekapitulasi uji hipotesis penelitian

\begin{tabular}{ccccc}
\hline & $\bar{x}$ & $S$ & $\boldsymbol{t}_{\text {hitung }}$ & $\boldsymbol{t}_{\text {tabel }}$ \\
\hline Pre test & 36,78125 & 9,53342 & \multirow{2}{*}{$-19,7282$} & 1,998972 \\
\cline { 1 - 3 } Post test & 79,90625 & 7,87548 & & \\
\hline
\end{tabular}

Berdasarkan Tabel 3 terlihat rerata pre test sebesar 36,78125 sedangkan rerata post test sebesar 79,90625. Simpangan baku pre test sebesar 9,53342 dan post test sebesar 7,87548 dan $t_{\text {hitung }}$ pre test dan post test sebesar $-19,7282$ sedangkan $t_{\text {tabel }}$ pre test dan post test sebesar 1,998972. Jadi bisa diartikan karena bahwa $-t_{\text {tabel }}<t_{\text {hitung }}<t_{\text {tabel }}$ yaitu $-1,998972<19,7282<$ 1,998972, berarti $H_{0}$ ditolak dan $H_{1}$ diterima. Maka data pada perlakuan post test setelah diberikan perlakuan model Think Talk Write (TTW) berakibat lebih baik daripada data pada pre test yakni sebelum diberikan perlakuan.

\section{Deskripsi Kemampuan Peserta Didik}

\section{Peserta didik KKMT Tinggi}

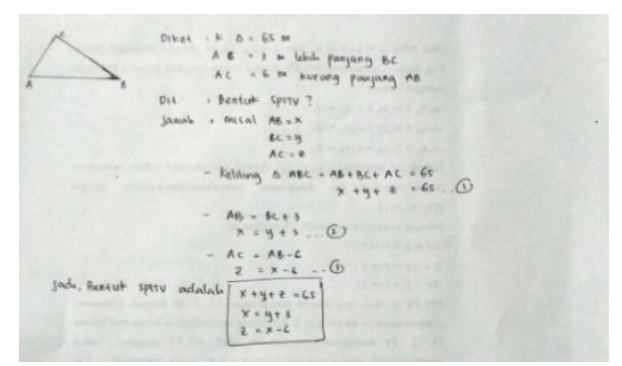

Gambar 1 Hasil Jawaban Peserta didik KKMT Tinggi

Berdasarkan Gambar 1, subyek ini mengerjakan soal tes dengan lancar tanpa kendala, subjek dapat menyelesaikan seluruh soal dengan benar. Peserta didik sanggup menuliskan gagasan matematis dengan tulisan berupa benda konkret, ilustrasi, tabulasi, dan aljabar. Peserta didik sanggup menggunakan bahasa sendiri dalam menjelaskan kembali uraian/paragraf matematika. Peserta didik sanggup mengutarakan kasus sehari-hari kedalam kalimat matematika. 
Peserta didik sanggup menjalankan ide, kondisi dan relasi matematika dan merencanakan cara penyelesaiannya. Peserta didik sanggup meggunakan metode penyelesaian dengan tepat dan sistematis. Peneliti melihat bahwa subjek dalam menyelesaikan semua soal test sangat sistematis dan rapi. Setelah memperoleh jawaban akhir, subjek mengecek semua jawabanya dan juga membuat kesimpulan dari jawabannya dan cocok dengan soal yang ditanyakan.

\section{Peserta didik KKMT Sedang}

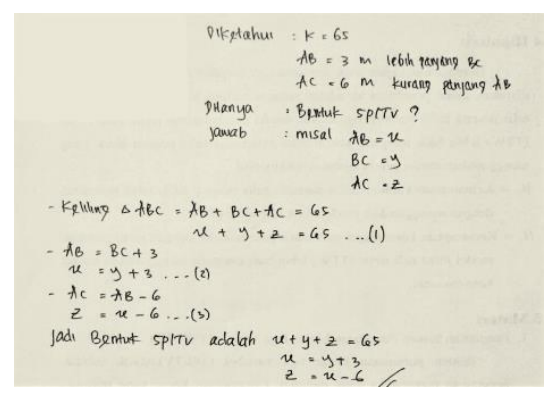

Gambar 2 Hasil Jawaban Peserta didik KKMT Sedang

Berdasarkan Gambar 2, subyek ini mengerjakan soal tes dengan lancar sedikit kendala. Subyek menyelesaikan seluruh soal, tetapi tidak semua jawabannya benar. Peserta didik sanggup menulis gagasan matematika secara tulisan tetapi masih rendah dalam mengilustrasikan kedalam benda konkret, ilustrasi, tabulasi, dan aljabar. Peserta didik mampu menggunakan bahasa sendiri dalam mengungkapkan kembali uraian/paragraf matematika. Peserta didik sanggup mengutarakan kasus sehari-hari kedalam kalimat matematika. Peserta didik sanggup menjalankan ide, kondisi dan relasi matematika dan merencanakan cara penyelesaiannya. Peserta didik sanggup meggunakan metode penyelesaian dengan sistematis. Setelah memperoleh jawaban akhir, subjek mengecek semua jawabanya tetapi tidak membuat kesimpulan dari jawabannya cocok dengan soal yang ditanyakan.

\section{Peserta didik KKMT Rendah}

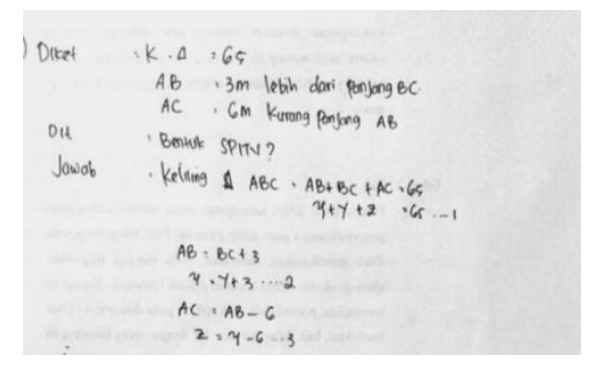

Gambar 3. Hasil Jawaban Peserta didik KKMT Rendah 
Berdasarkan Gambar 3, subyek ini mengerjakan soal tes kurang lancar banyak kendala. Subyek menyelesaikan seluruh soal yang diberikan tanpa terkecuali tetapi subyek mengerjakan dengan asal-asalan. Peserta didik mampu menuliskan gagasan matematis secara tulisan tetapi masih rendah dalam mengilustrasikan kedalam benda konkret, ilustrasi, tabulasi, dan aljabar. Peserta didik sanggup menggunakan bahasa sendiri dalam mengungkapkan kembali uraian/paragraf matematika. Peserta didik sanggup mengutarakan kasus sehari-hari kedalam kalimat matematika. Peserta didik sanggup menjalankan ide, kondisi dan relasi matematika dan merencanakan cara penyelesaiannya. Peserta didik sanggup meggunakan metode penyelesaian tetapi tidak sistematis. Setelah memperoleh jawaban akhir, subjek tanpa mengecek semua jawabanya dan tidak membuat kesimpulan dari jawabannya cocok dengan soal yang ditanyakan.

\section{SIMPULAN}

Berdasarkan hasil rekapitulasi tentang pengaruh model Think Talk Write (TTW) terhadap kemampuan komunikasi matematis tulis peserta didik kelas X-IPS 3 SMAN 3 Bojonegoro diperoleh kesimpulan yaitu kemampuan komunikasi matematis tulis peserta didik tumbuh sedikit demi sedikit setelah mendapat treatment model Think Talk Write (TTW), dapat diketahui dari skor pre test yang berarti sebelum diberikan treatment model TTW rerata yang dihasilkan adalah 36,78125 dan dari skor post test yang berarti setelah diberikan treatment model TTW rerata yang diperoleh adalah 79,90625. Sedangkan berdasarkan hasil perhitungan uji normalitas $L_{\text {hitung }}<L_{\text {tabel }}$ yaitu $0,104652<2,039513$ menghasilkan data berdistribusi normal. uji homogenitas $F_{\text {hitung }}<F_{\text {tabel }}$ yaitu $1,465357<1,822132$ menghasilkan populasi homogen. dan uji hipotesis kedua test menghasilkan $-t_{\text {tabel }}<t_{\text {hitung }}<t_{\text {tabel }}$ yaitu $-1,998972<19,7282<$ 1,998972, dengan $H_{0}$ ditolak dan $H_{1}$ diterima maknanya dengan treatment Think Talk Write (TTW) kemampuan komunikasi matematis tulis peserta didik menjadi lebih baik daripada sebelum diterapkan treatment model pembelajaran Think Talk Write (TTW) . 


\section{UCAPAN TERIMA KASIH}

Penulis mengucapkan terimakasih kepada Program Studi Pendidikan Matematika, FKIP, Universitas Nahdlatul Ulama Sunan Giri Bojonegoro atas dukungan dan fasilitas penelitian.

\section{DAFTAR PUSTAKA}

Hamdayama, J. (2014). Model dan Metode Pembelajaran Kreatif dan Berkarakter. Bogor: Ghalia Indonesia.

Hamzah, A. (2014). Perencanaan dan Strategi Pembelajaran Matematika. Jakarta: PT. Raja Grafindo Persada.

Muslisrarini. (2014). Perencanaan dan Strategi Pembelajaran Matematika. Jakarta: PT. Raja Grafindo Persada.

Rahmawati, C., \& Zhanty, L. (2019). Analisis Kemampuan Komunikasi Siswa Menengah Terhadap Resiliensi Matematis. Jurnal Pembelajaran Matematika Inovatif, 2(3), 147-154. http://dx.doi.org/10.22460/jpmi.v2i3.p147-154

Setiyawan, R., Darmawan, P., \& Prayekti, N. (2019). Analisis Kemampuan Komunikasi Matematis dalam Menyelesaikan Soal SPLTV (Sistem Persamaan Linier Tiga Variabel):Kasus Pada Siswa SMA Kelas X IPS. Prosiding:Konferensi Nasional Matematika dan IPA Universitas PGRI Banyuwangi (Vol. 1, no. 1, p. 31-43).

Sugiyono. (2015). Metode Penelitian Pendidikan Pendekatan Kuantitatif, Kualitatif, dan $R \& D$. Bandung: Alfabeta.

Umar, W. (2012). Membangun Kemampuan Komunikasi Matematis dalam Pembelajaran Matematika. Jurnal Infinity, 1(1): 1-9.

Wardhana, I., \& Lutfianto, M. (2018). Analisis Kemampuan Komunikasi Matematis Siswa Ditinjau dari Kemampuan Matematika Siswa. UNION:Jrnal Ilmiah Pendidikan Matematika, 6(2), 173-184. https://doi.org/10.30738/.v6i2.2213 